\title{
A Preliminary Assessment of Chonaikai and Banjar From the perspectives of the Comparative Sociology on the Community
}

\author{
I Made Budiana $^{1}$, Ayami Otsuka ${ }^{2}$, Naoki Yoshihara ${ }^{3}$ \\ Japanese Literature, Faculty of Arts \\ Udayana University \\ Denpasar, Bali \\ budi.hybrid@gmail.com \\ Yokohama National University
}

\begin{abstract}
Today, with the advancement of globalization, it is essential to clarify how the local communities are changing from a viewpoint of comparative sociology, in order to evaluate the changes in the modern society from a broader point of view. This paper attempts to make a preliminary, comparative consideration between chonaikai in Japan and banjar in Bali. The results revealed the following: 1) local communities have always been placed in a top-down government framework through history; 2) yet, it demonstrates, from time to time in history, a dynamism rooted in the native social theory and customs; and 3) after all, local communities have reached a critical phase in the modern, post-colonial stage.
\end{abstract}

Keywords: community, chonaikai, banjar, comparative sociology

\section{INTRODUCTION}

Commonality arising from people's "sharing of lives" has always been thought to exist at all times and places, and, it actually does exist. It is manifested in the community as a specific form, but there is no established theory on how to comprehend communities. Incidentally, a sociologist named Hillery (1955) mentioned that there were as many definitions of the community as the sociologists dealing with the community more than a hundred years ago. Now, a century later, definitions of the community are considered innumerable. Given such circumstances, and yet to seek the greatest common provision, the following definition by Bell and Newby (1976) perhaps provide a good reference. They define the conditions for a community as 1) a geographical proximity based on a specific area of residence; 2) a local, social system which is based on interactions of social groups and local institutions with localized and relative borders; and 3) rapport, i.e. bonds among the people which are characterized by strong social ties, a sense of belonging, and warmth based on the character of the members. In other words, according to Bell and Newby, a community is comprised of territory, local interactions, and a sense of proximity. Especially notable here is that a community premise a settlement. Indeed, the greatest feature of the community theory until today has long been that it was inseparable with sedentarism.

With the recent advancement of globalism, however, the concept of community, which holds a premise of settlement and considers itself as a system of people's interactions and sentiment/consciousness rooted in a specific territory, is increasingly being questioned. At the very least, such a concept of the community has lost its reality. A borderless flow of people, things, matters, and information has widely generated societies beyond any national society. This has resulted in the eroding of the substantial foundation of the community, rooted in territoriality where de-territorialization of social life and social relationships progress. Now, the border between moving and settling has become ambiguous, and the local community based on territoriality has shifted back in the society, and instead, a networked community, which is rooted in borderless interactions among people, has emerged to the foreground of society. This point will be discussed in detail in a separate paper, but in any case, it is certain that the concept of community is under question today.

This paper aims to illustrate where the existing base lies in today's societies, and how such possibilities can be disclosed through a comparative case study between two nations/societies - Japan and Bali. Here, as a preliminary consideration, the focus is given specifically to an overview and historical changes of chonaikai (block association) and banjar 
(hamlet).

\section{CHONAIKAI AND BANJAR: A SKETCH}

a. Chonaikai as a "modern community"

Let us begin by looking at chonaikai in Japan. Most Japanese, at least until now, have commonly associated community with chonaikai. In fact, chonaikai exists in any municipality and is widely acknowledged. The existence of chonaikai is also known among foreign researchers with interests in Japan. By the way, Pekkanen, who has been conducting research on Japanese society, refers to chonaikai as an organization which consists of the residents of a community within a specific border and engages in a variety of activities relevant to that community (Pekkanen, 2006). In addition, for Berque, well-versed with Japanese culture, chonaikai embodies the firmness of chien (regional ties) in the modern Japanese society and there is the "community of the day" (Berque, 1986). Positively or negatively, it seems that chonaikai is viewed as something that carries the unique characteristics of Japanese society and culture.

For people in the West, chonaikai is something of a substantially different nature that is not based on voluntary membership. Any group that "you automatically become a member just by residing in a specific area, without clearly indicating your will to join or otherwise" is unimaginable or improbable. For this reason, it was often disrespected as representing grassroots conservatism. On the contrary, there has arisen a standpoint which tries to see the possibility of a topological relationship of chien (neighbors), as Berque did.

By the way, it is not necessarily the case that there is a consensus on how to grasp chonaikai, even in Japan. This reminds us that there was an intense discussion around whether to see chonaikai as a form of a culture or a legacy of feudalism (Yoshihara, 2000). This was the so-called "chonaikai controversy," which dominated in the academia of sociology in the 1950s, although such an attempt to grasp chonaikai structurally has not been actively made since then. Instead, a certain number of studies which analyzed it from its functional point of view have been accumulated. Under such circumstances, it is the most commonly accepted definition of chonaikai to seize it from the following five points, namely 1) exclusive locality, that is, a specific area; 2) membership by household; 3) participation by all households; 4) having an integrative function; and 5) representing the locality. These five characteristics of chonaikai emphasized by this view are partly compatible with the three conditions that Bell and Newby (1976) point out, indicating that chonaikai represents the de facto community, or more precisely, the local community.

\section{b. Two-layered Banjar}

Let us next look at banjar. Banjar is the base of Balinese society and can be compared with the above-mentioned chonaikai. Strictly speaking, it is a hamlet, but considered here as an equivalent of $R T / R W$ (chonaikai/tonarigumi) lying at the base of Javanese society and, therefore, represents one form of the local community. Banjar is central to the "pluralistic collectivism" as Geertz describes (Geertz, 1963, p.85). Warren also mentions that:

Everyday life in the villages of South Bali is through these intersecting but semi-autonomous corporate units of a special purpose character: the banjar is the civic community; the subak (agricultural associations) organize irrigation and other aspects of farming which require common co-ordination; the dadia or soroh is a kin-group based on descent through the male line; pemaksan (temple support groups) are responsible for the maintenance of village shrines and the organization of much of local ritual beyond the life cycle and ancestral ceremonies of family and kin-groups; and seka include clubs and voluntary work-groups formed to do just about anything else. Banjar, pemaksan, and seka usually draw their memberships from within the desa, while subak and dadia memberships frequently cross-cut it. The result is a complicated, nevertheless highly structured, arrangement of overlapping but non-coordinate corporate groups... (Warren, 1993, pp.7-8).

As understood from here, banjar itself is a form of the local community and intersects with a number of institutions and organizations (that is, a networked community, is described with the term already used in this paper) which carry a specific function in everyday life. It belongs under desa (village) through people. But banjar clearly differs from chonaikai in Japan or $R T / R W$ in Java, in terms of taking the two-layered structure, consisting of adat (local customary unit) and dinas (government unit).

Today, banjar is placed at the lowest of the multi-layered hierarchical system covering the state to neighborhood levels. Desa (village), the immediate upper tier, consists of two-layers: desa adat (local customary village), which deals with a series of courteous and symbolic matters, and desa dinas (government village), which administers public affairs. Banjar, the lower tier of desa, also takes two layers, namely banjar adat and banjar dinas. Although this differentiation between adat and dinas can be traced as far back as when the island of Bali as a whole was placed under Dutch colonial rule (i.e.1906 1907). According to Kagami (2000), it was only in 1979 when these were clearly institutionalized under the Desa Administrative Law. Adat originally acts on awig-awig (basic regulation) which is based on the Balinese Hindu dogma. The process of institutionalization, including this point, will be discussed in the next chapter. Here, it should be pointed out that the above-mentioned two-layered structure richly praises the cosmology of desa- 
banjar, by maintaining the state of "pluralistic collectivism." That is to say, this cosmology is very characteristic of the Balinese community. In the next chapter, the preliminary sketches of the history and origins of chonaikai and banjar described above will be looked at in more detail.

\section{ORIGIN AND THE HISTORY OF CHONAIKAI}

\section{a. Prehistory of Chonaikai}

Chonaikai is a typical local resident organization/local community which emerged with the development of the modern Japanese society. There are a number of views as to where to place the prototype of chonaikai, but it is certain that it has long prehistory as rimpo seido (neighborhood system) in premodern times. Here, the prehistory of chonaikai will be overviewed according to " $A$ Preliminary Study of the Neighborhood Associations of Japan," a special report written by Analysis and Research Division of the Civil Information and Education Section, GHQ, in January 1948 under the American Occupation (GHQ/SCAP, CIE 1948).

According to this report, the prehistory can be divided into two phases: namely 1 ) the introduction of the five-man neighborhood association system at the time of the Taika Reform, and 2) the goningumi (five-man group) as a local administrative organ in feudal Japan of the Tokugawa era. In the first phase, the primordium is seen as the introduction of the five-man neighbourhood association consisting of five households at the time of the Taika Reform (of $645 \mathrm{CE}$ ), following the ho system in China during the Tnag Dynasty (618-907 CE), which was then institutionalized by Taiho Ritsuryo (Taiho Ordinance) in $701 \mathrm{CE}$ and by Yoro Ritsuryo (Yoro Code) in $718 \mathrm{CE}$. Under this institutionalization, the functions of the neighborhood association were established as maintaining order, collective economic responsibility, and mutual aid. The system of neighborhood association did not penetrate the entire society, despite the multiple efforts of law amendments and expansion of the scope of the laws to ensure the smooth execution of the above functions. Rather, the five-man neighborhood association as an institution began to decline in the Heian period (from 794 to $1185 \mathrm{CE}$ ), and have completely faded by the middle of the Heian period. In the Kamakura period (from 1185 to $1333 \mathrm{CE}$ ), the five-man neighborhood association became just a name only as various institutions of the samurai class were being formed (and these will be institutionalized as "Buke Myomokusho" in the later Edo period). On the other hand, a movement of collectivization of neighbors traced from the concept "ho" sustained as cho and machi.

The signs of the revival of the five-man group emerged as a way to, especially, deal with lawlessness and riots at the end of the Muromachi period. It was established as an institution to maintain the feudal order as a result of shoring up by the government for the purpose of prohibiting Christianity, policing of vagrants, especially a master-less samurai, on the rise, and ensuring the levying of nengu (tax) gradually becoming a heavier burden during the third Shogun, Iyemitsu, of the Tokugawa era. It was under such circumstances, that the second phase mentioned earlier emerged. With the stabilization of bakuhan taisei (the shogunate), the function of the "five-man group" initially anticipated for maintenance of the peace and was gradually shifted to normative and economic aspects so that the rules and pledges of the five-man groups came to cover almost all domains of everyday life. In any case, the five-man groups have become a responsible, local administrative unit and basic cooperative organization of the local residents throughout the Tokugawa period.

\section{b. The Birth of Chonaikai and the Process of State Control}

The rimpo organization overviewed above was the "prototype" of chonaikai, but it did not directly lead to chonaikai. The functions of the "five-man groups" were eradicated during the Meiji Restoration (from 1867 to 1889). This was dictated by the delivery of the shisei-chosonsei (the reorganization of cities, towns, villages) in 1888. The nature of the "five-man group" as an administrative institution was completely lost by this time. The "five-man groups" were separated from administration and sustained as neighborhood mutual-aid organizations where the residents help each other. It was not until 1908, even after the Russo-Japanese War of 19041905, (when the revival of the five-man group, once withdrew from the center stage of the history, was mentioned in the imperial ordinance of Boshin Shosho), that the "five-man group" came back to life in a public sphere as chonaikai. By the way, one of the initial catalysts for the emergence of chonaikai in Tokyo was the jikeidan (civil defense group) that was widely organized in line with the intention of the military and police after the Kanto Earthquake. The jikeidan was ordered to dissolve later, as it was held responsible for the massacre of the Koreans (Matsuo, 2003), and it is known that some had been absorbed into chonaikai at the time of dissolution, depending on the areas. Nonetheless, it is during the period of noson keizaikosei undo (the campaign for the renovation of the village economy) after the Showa Depression, followed by the outbreak of the China Incident, that chonaikai emerged as an administrative layer. Chonaikai was formed to mutually help each other against the impoverishment of the agrarian villages as well as to back up the warfare from grassroot levels. Most of the chonaikai in the old city area of pre-war Tokyo and agricultural suburbs were said to be established during this period (Tokyo City, 1934). 
With the intensification of the Total War System, henceforth, the state control over chonaikai was strengthened. The direct reason for that can be seen in various national planning with regards to the reform of local municipalities, with its beginning owing to the amendments of prefectural, municipal, and town and village systems. All these plans failed, however, and organization of the national system resulted by the proclamation of the Instruction No.17 by the Ministry of the Home Affairs on September 11, 1940. Furthermore, various instructions issued by the Local Bureau of the Home Ministry were delivered to municipalities, wards, towns, and villages, then finally to chonaikai via jokai. As such, the state control over chonaikai reached the highest degree, making chonaikai a semi-administrative body which deals with difficulties of the home-front and was responsible for rationing of daily necessities.

After the war, chonaikai was dissolved by the Potsdam Cabinet Order No.15 in May 1947, because of its undemocratic nature and especially for its responsibility to support warfare at the basic levels of society. But it remained in effect in many of the areas by changing its name ${ }^{1)}$ (Yoshihara, 1989). This is how chonaikai has seamlessly sustained itself to this day after its arrival in modernity.

As looked at here, chonaikai as a local community has been consistently placed within the "top-down" government framework from time of the rimpo seido/five-man groups from prehistory to the present. At the same time, it cannot be denied that it has occasionally played the role of "sharing of lives" among the people in history. In fact, after the decline of the social control function through a long conflict, there have often been cases where the function of mutual-aid would emerge to the forefront of the society. On the whole, therefore, it is not wrong to grasp chonaikai in the context of "top-down" control, but it must not be forgotten that it had sustained the flexibility owing to the fact that it had not necessarily been framed within the local institutions.

\section{HISTORY OF DESA AND INSTITUTIONALIZATION OF BANJAR}

a. History of Desa and its Two-Layered Structure

As mentioned earlier, banjar belongs to the lower tier of desa. The precise origin of desa has not been made clear ${ }^{2)}$, but karma, which led to desa was already existent in the $9^{\text {th }}$ century. The area of krama is desa pakraman, which is said to have been central to the formation of the present desa. The effect of Java-Hindu then exerted in the $14^{\text {th }}$ century, when desa was integrated into a dynasty and was given two functions: that is, a religious function, as seen in ancestor worship, and a political function. Later, when a perbekel (a village chief), who supports the king, began to govern desa during the British colonial Raffles period, desa was regarded as "rechtsgemeenscap," a small republic with a unique customary law and rules. The king of the dynasty ruling desa withdrew and Java was ruled by the Dutch, and then, perbekel came to be appointed as a chief of a new administrative village (like a local government) set by the colonial government, not as a chief of a customary group/community village. There appeared a contradicting relationship where the old desa, based on tradition of desa pakraman, and the new desa, an administrative village, exist in parallel. The former then became to be called desa adat (local customary village).

In any case, today, the two-layered structure of desa adat and desa dinas apparent in desa level all over Bali was derived from the preparation of the lowest organizations which was conducted in line with the establishment of the upper bodies under the colonial rule. The colonial government, by the way, prescribed people to comply with adat (custom) separately from their own country's local government laws, but it was virtually just inserting some of the rules of the Dutch local government laws into a culmination of the customary law within the relevant areas ${ }^{3)}$. Thus, the origin of the administrative village was unlocked, but in reality, it was sustained in a number of areas for a long period of time even after independence in 1950.

It is only in 1979 when this administrative village came to an end. The Village Government Law (UU No.5 Tahun 1979 tentang Pemerintahan Desa) delivered that year made desa as a national administrative organization substituting the administrative village. Here, while customs of desa are being approved of, it was set that desa consist of kepala desa (head of desa) and Lembaga Musyawarah Desa (LMD: Village Consultative Council) anywhere in Indonesia. In Bali, however, the Village Government Law, with its preamble stating its goal to protect the diversity of the village forms and the local customs, rather promoted the movement where the development of desa adat was actively sought. Further, the State Ordinance regarding Locality, Function, and Roles of the Customary Villages as Social Units in the Customary Law in Bali (Peraturan Daerah Propinsi Daerah Tingkat I Bali no.6 Tahun 1986 tentang Kedudukan, Fungsi dan Peranan Desa Adat Sebagai Kesatuan Masyarakat Hukum Adat Dalam Propinsi Daerah Tingkat I Bali), delivered in 1986, actually gave legal authorization to desa adat. The Local Government Law (UU No.22 Tahun 1999 tentang Pemerintahan Daerah), delivered in 1999, later dictated the establishment of desa adat as an autonomous selfgoverning organization.

\section{b. Institutionalising Banjar}

As mentioned earlier, banjar and desa exist together, but it is not clear either when banjar was established or what the prototype of banjar is, other than that banjar was originally used to express the 
assembly of karang (residential compound). It was upon the delivery of the Village Government Law in 1979, mentioned earlier when banjar was clearly positioned within the institutional frame. As shown in Figure 1, the Village Government Law "establish[es] a multi-tiered administrative hierarchy from the neighborhood through provincial level[s]" (Warren 1993, p.239). Thus, the two-layered structure of dinas and adat was institutionalized under banjar/lingkungan (the subdivision of nonautonomous villages), the lower tier of desa/kelurahan (the non-autonomous village). It also mentions detailed rules for kepala desa and refers to banjar dinas (that is, dusun), banjar adat, and kepala lingkungan (head of lingkungan). Kepala dusun ( head of dusun ) is appointed by a camat ( a district head) and has become a public servant submitting to kepala desa.

For several years immediately after the enactment of the Village Government Law, however, the position of kepala dusun remained unfilled in most banjar. This was largely influenced by insufficient national budget to meet the sudden increase of salary required for the appointment of kepala dusun, in addition to the confusion by the enactment of the Law on the banjar-side. The gubernur (governor) of Bali state enacted a state ordinance regarding desa pakraman in 2001, promoting banjar to appoint kepala dusun. Banjar, without kepala dusun, thus decreased, establishing the two-tier structure of "dinas-adat" and "dusunbanjar." If given a thought, the two-tier structure of banjar corresponds to that of desa through the enactment of adat and the internalization, institutionalization, and dinas-ation of desa. This itself is considered to represent the institutional reform at the bottom of the abovementioned "multitiered administrative hierarchy." In this view, it was considered that institutional reform occurred at the appropriate time during the post-colonial phase through decentralization/democratic system after the dictatorship during the development period, not during the colonial phase, where a unique social principle/adat (which has been placed deep inside desa) was either "displaced to the other side" or "relegated to the edge."

\section{EXISTING FORMS OF CHONAIKAI AND $B A N J A R$}

\section{a. Condescending Eyes}

Through the historical development of chonaikai and banjar, as looked at in parallel above, what emerges in common is that both have always been exposed to condescending eyes. Furthermore, the direction of eyes is towards "the social," which have been uniquely held deep inside local communities. These were symbolized in the rinpo seido (system of the neighborhood association) for chonaikai and in gotong royong (mutual aid) for banjar, respectively. Interestingly, these were once dis-embedded in the modern/post-colonial context, then re-embedded later. We can read off the persistent pattern of historical adoptions of local communities based on administrative reasons. In another view, this suggests that the local communities hold a type of dynamism which has sustained through history.

The labeling of communities with words, such as "too old" or "too traditional," is used to describe chonaikai today. However, this does not necessarily deny the dynamism mentioned above. In this view, it is worthwhile to note a passionate gaze being given to the dynamism hidden in the traditional event of banjar, as symbolically seen in the ajeg Bali (Bali revival movement). Yet, it is necessary to carefully look at how these dynamisms are caught up in the historical phases.

\section{b. Historical Phases of the Dynamism}

In searching the historical phases, the effect of globalization, and especially of global tourism, cannot be ignored. In Japan, interests in security issues have grown as a result of the increase in inbound tourists, and the local communities are being made responsible for this purpose. For example, chonaikai are being reformed as tonarigumi for disaster prevention purposes. Within this movement, intentions can be seen to utilize the human resources and networks, which have fostered "sharing of lives," serving as the basis of such dynamism. Integrating such intrinsic resources hidden in the local communities can act to seize the locality to promote further globalization on the whole ${ }^{4}$.

On the contrary, in Bali, adat in bajar and rituals and ceremonies associated with it are becoming resources for tourism, losing their original meaning/symbolic systems, as Bali establishes itself as a global brand. Ajeg Bali discussed earlier, is also increasingly exposed to secularization brought by global tourism. The dynamism shown at the bottom tier of banjar is considered high for its instrumental utility.

Again, in the trend looked at above, it should be noted that the weakening of chonaikai in Japan and losing the meaning of the two-layered structure of 'adat-dinas' and 'dusun-banjar' in Bali are unavoidable. Regardless of the details, this is causing the breakdown of the dynamism which has supported the local community from the foundation. Ironically, chonaikai is following the path to collapse as more top-down leverages are implemented in Japan, and the promotion and revival of policy for the customary culture, led by the governor as decentralization progresses, and are resulting in the weakening of desa adat, rather than strengthening it in Bali.

In any case, both chonaikai and banjar are 
standing at the crossroad of global changes. There is also a view of these dynamisms from traditional communitarianism. If this position is taken too far to the front, however, there is a risk of missing the "presence" of the local communities by closing the eyes on the historical phases of the dynamism.

\section{CONCLUDING REMARKS}

This paper placed the point of discussion on where the existing base of today's community stands and how its possibilities are opened through a case study of two nations/societies: Japan and Bali. As it became clear in the discussion above, the discussion did not necessarily go into depth on the agenda itself. Rather, it only gave a preliminary view regarding the issue. It may be more appropriate to say that it posed several points of discussion to research fuller. Yet, this paper revealed the following three points: 1) local communities have always been placed in the top-down government framework through at history; 2) yet, it demonstrates, from time to time in history, a dynamism rooted in the native customs of Japanese and Balinese culture; and 3) after all, the local community in each culture have reached a critical phase in the modern/post-colonial stage. These conclusions are just a preliminary attempt at researching this area. Each of these points should be closely examined in the following papers.

The main purpose of the next paper would be to clarify the existing forms of the community from the theoretical horizon of comparative sociology. Specifically, case studies from the chonaikai in a suburb of Tokyo area and bajar in an inner area of metropolitan Denpasar will be looked at to illustrate a whole picture of the communities, including not only local but also networked communities, and their active dynamism. At the same time, the structural characteristics overshadowing the two societies should also be revealed. Finally, then, a trial to bring a paradigm shift to the communities would be considered through a discussion of the findings. This paper, in any case, outlined the first step towards such an agenda-setting research project.

Note:

1) This is why chonaikai was born one after another, just as "bamboo shoots after rain," soon after the Potsdom Decree. This means that they, in reality, existed even under its ban.

2) The term desa was originally derived from the Sanskrit, with the meaning of "place" or "reference."

3) According to Diantha, the reaching horizon of the rural policy under the colonial administration can be found in the Native Government Ordinance (Staatblad 1906 No.83 tentang Inlandsche Gemeente Ordonantie) of 1906, and the Outer territory-Native Government Ordinance (Staatblad 1938 No.490 tentang
Inlandsche Gemeente Ordonantie) of 1938 (Diantha 2003).

4) The concept of "glocal attractor" by Urry is helpful regarding this point (Urry 2003).

\section{REFERENCES}

[1] Bell, C. and Newby, 1976, "Communion, communalism, class and community action: the sources of new urban politics," in D. Herbert and R. Johnson eds., Social Areas in Cities, Wiley.

[2] Berque, A., 1986, Le sauvage et l'artifice-Les Japonais devant la nature, Editions Gallimard.

[3] Diantha, I Made Pasek, 2003, "Eksistensi Desa Menurut UU No.22 Tahun 1999,"in I Gede Janamijaya et.al. (eds.), Exsistensi Desa Pakraman di Bali, Yayasan Tri Hita Karana Bali.

[4] Geertz, C., 1963, Peddlers, and Princes: Social Change and Economic Modernization in Two Indonesian Towns, University of Chicago Press.

[5] GHQ/SCAP, CIE, 1948, A Preliminary Study of the Neighborhood Association of Japan.

[6] Hillery, G. A., 1955, "Definitions of Community: Areas of Agreement," Rural Sociology, 20 (2): 111-123.

[7] Kagami, H., 2000, Seisaku bunka no jinruigaku (Anthropology of Political Culture), Sekai shiso sha.

[8] Matsuo, S., 2003, Kanto daishinsai to kaigenrei (the Great Kanto Earthquake and martial law ), Yoshikawa kobun kan.

[9] Pekkanen, R., 2006, Japan's Dual Civil Society: Members Without Advocates, Stanford University Press.

[10] Tokyo City, 1934, Tokyo shi no chonaikai (Chonaikai in Tokyo City).

[11] Urry, J., 2003, Global Complexity, Polity.

[12] Yoshihara, N., 1989, Sengo kaikaku to chiiki juminsosiki (The Post-war Reform and the Neighborhood Association), Minerva Shobo.

[13] Yoshihara, N., 2000, Ajia no chiiki jumin soshiki (Neighborhood Associations in Asian Societies: on the Chonaikai, Kaifong, and RT/RW), Ocha no mizu shobou.

[14] Warren, C., 1993, Adat and Dinas: Balinese Communities in the Indonesian State, Oxford University. 